los estudios del arte novohispano, pues él era uno de los colegas mayores del Viejo Mundo, con quien existía comunicación.

Elisa VARGas Lugo

\title{
JAN BIALOSTOCKI \\ (1921-1988)
}

En Varsovia, ciudad que le vio nacer, falleció el 25 de diciembre de 1988 el notable historiador del arte Jan Bialostocki, autor de una obra considerable formada por ensayos publicados en revistas especializadas y varios libros que le sitúan como un distinguido humanista. Sus participaciones en los congresos ordenados en torno de las obras de arte, así como las cátedras universitarias que atendió tanto en Europa como en los Estados Unidos de Norteamérica, resaltan su valía de manera idéntica con lo que publicó. Figuró también como Director del Instituto de Historia del Arte de la Universidad de Varsovia, y en el Museo Nacional de la capital polaca, fue curador de la Galería de Pintura Europea.

Jan Bialostocki profesó el método iconológico del inolvidable Erwin Panofsky; sus estudios más relevântes están comprendidos dentro de esa discipilna. En el libro Ars Auro Prior, publicado en Varsovia en 1981 en su honor, con motivo de sus sesenta años de edad, se reunieron 115 ensayos escritos por autores de distintos países; entre esas colaboraciones se encuentra la extensa bibliografía de cuanto había escrito, con esmerada entrega, hasta 1980; los temas que trató son múltiples, si bien predominan los referentes a la pintura. De esa labor sobresaliente, por desgracia un solo libro se ha publicado en español: Estilo e iconografía. Contribución a una ciencia de las artes (Barcelona, 1972). En el año de su muerte apareció en Viena su último libro: The Message of Images.

En diversas ocasiones fue huésped distinguido de la Universidad Nacional Autónoma de México; en julio de 1976 participó en el Coloquio Internacional de Historia del Arte, organizado por el Instituto de Investigaciones Estéticas.

Con la desaparición de Jan Bialostocki, la cultura de su patria ha sufrido una pérdida irreparable; otro tanto se puede afirmar respecto al mundo de las humanidades.

XAVIER MoYssÉn 
DOI: http://dx.doi.org/10.22201/iie.18703062e.1989.60.1537

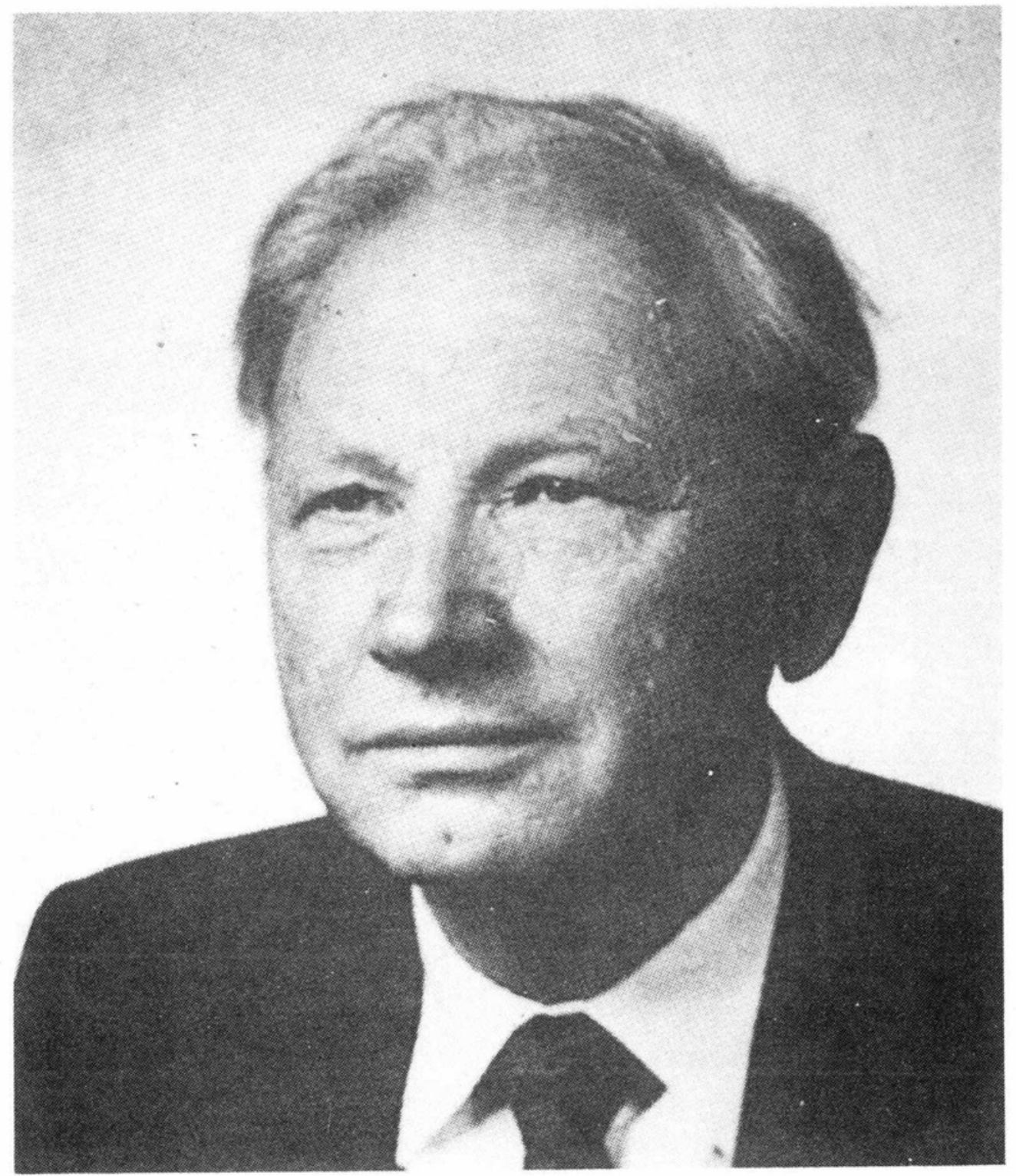

Jan Bialostocki. 